\title{
Hydro-Oceanographic and Bathymetric Survey in Tanjung Merah as a Basis for Modelling Coastal Spatial Plans of Bitung City
}

\author{
Joyce C Kumaat ${ }^{*}$, Kalvin S Andaria, Denny Maliangkay \\ Geography Study Program, Manado State University, North Sulawesi, Indonesia
}

\begin{abstract}
The purpose of this study was to examine the parameters of Hydro-Oceanography (Tidal and Tidal Currents) and Bathymetry (Sea Depth) in Tanjung Merah, Bitung City. The method used in this research is a field survey method. The survey was carried out at the research location, precisely in Tanjung Merah, Matuari District, Bitung City. Equipment such as GPS Fish Finder, Floater Current Meter, Tidal Pole and Boats are supporting devices in obtaining accurate data on tides, tidal currents, and bathymetry in the waters of Tanjung Merah. The results showed that the tidal current conditions at the study site with several variations in the depth of the tidal current velocity ranged from $0.2-0.3 \mathrm{~cm} / \mathrm{sec}$ with the dominant direction of the current towards the south. While the tides using tidal harmonic analysis for 15 days of observation, the Formzal Index is 0.93 which means that the tides in this location are mixed type with a single daily trend. Bathymetric conditions in Tanjung Merah identified the topography of the bottom of the waters is steep with depth variations between $2-30$ meters along the coast of Tanjung Merah while shallow areas are found at the mouth of the Tanjung Merah river.
\end{abstract}

Keywords: Hydro-oceanography, Bathymetric, Tides, Coastal

\section{Introduction}

The development of survey and mapping technology in coastal areas over time has developed in the design and accuracy of data collection [1], as well as in data processing which reaches thousands of data that can be easily processed using software such as Surfer, AutoCAD , ArcGIS, and Q Gis. Measurement of water depth in coastal areas is known as bathymetric survey where, in conducting this survey, several equipment will be used during the survey such as: Global Positioning System (GPS) which functions to measure the position of the ship in motion, Fish finder or Echosounder which functions to measure the position of the ship in motion [2][3]. measuring the depth of the sea and the survey vessel itself which is used as a floating vehicle in the implementation of bathymetric surveys. The implementation of the bathymetric survey is part of the hydrographic survey, where the implementation of this hydrographic survey is to map the topography of the seabed and other waters or specifically referred to as bathymetric mapping. Bathymetric mapping is a fundamental necessity to provide spatial information for activities, planning and decision making related to the information in the maritime field. Utilization of bathymetry maps in the marine sector is used in building a coastal area planning database, especially in allocating space according to its function. This research is an initial study in building a database for the coastal area of Bitung City, with Tanjung Merah in Matuari Bitung District as the starting point for conducting a survey. The Tanjung Merah area is one of the strategic areas, this area is currently being built a Special Economic Zone with a priority on the capture fisheries industry. The purpose of this study was to examine the parameters of hydrooceanography (tidal and tidal currents) and bathymetry in Tanjung Merah, Bitung City.

\section{Research Methods}

\subsection{Research Location}

This research was conducted in Tanjung Merah Bitung City. Time of research in June - July 2021 (Figure 1).

\footnotetext{
* Corresponding author : joykekumaat@unima.ac.id
} 


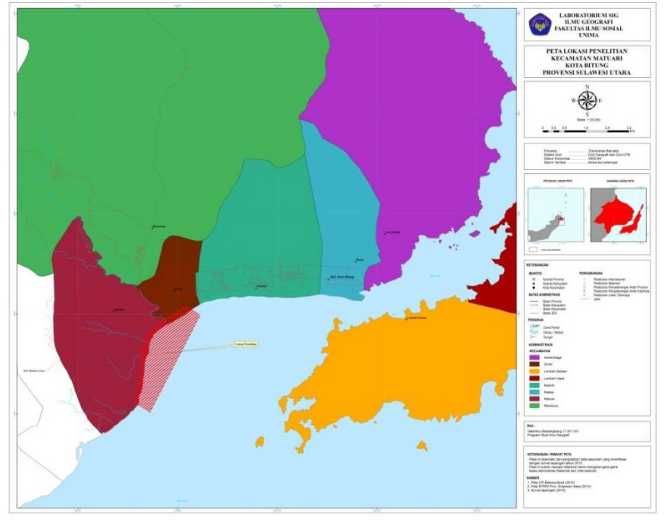

Fig. 1. Map of research location

\subsection{Research Tools and Materials}

The equipment used in this study is the boat survey used as a float at the time of measurement of the depth of the water, Garmin GPS 585 plus include Fish Finder, Tides Pole for measuring the ebb during the 15 days of observation, Floater Current Meter to measure the tidal current location research.

\subsection{Data Collection and Analysis Techniques}

Current and tidal measurements are carried out simultaneously, where for tidal currents measurements are made at onshore and offshore points. Measurement of ocean currents used a current meter type Flow Probe Global Waters 101, with a computerized system by recording the maximum velocity and average velocity in centimeters/hour. As for the direction of the current, a floater is used with a compass as a guide. Current data retrieval performed at two sampling points in onshore and offshore, with three measuring depth is $0.2 \mathrm{~d}, 0.6 \mathrm{~d}$ and $0.8 \mathrm{~d}$ where $\mathrm{d}$ is the depth gauge. Current data analysis is to calculate the maximum current based on the formula developed by, namely [1][4]:

$U_{-} \max =A \sqrt{ }(g / d)$

where:

Umax $=$ maximum tidal current velocity $(\mathrm{m} / \mathrm{s})$,

$\mathrm{A}=$ tidal amplitude

$\mathrm{g}=$ acceleration due to earth's gravity and

$\mathrm{d}=$ water depth

The distribution of surface currents used langrangian method is by measuring the flow at any point of measuring (sampling) that the set-in advance using a Garmin GPS type C60. Dispersion mapping surface current used the software Surfer v15 with kriging method. Tidal observations performed 14 and 29 days of the month (piantan - lunar days) continuously, data measurement results are presented in the form of tidal harmonic components in the analysis by the method of admiralty. The application of the admiralty method is intended for short daily data observations. Daily data are then analyzed tidal harmonic tidal constants are modeled by the equation [1] [4]:
$\mathrm{y}_{\mathrm{b}}=\mathrm{A}_{\mathrm{b}} \cos (\omega \mathrm{t}+\phi)$

With :

$\mathrm{yb}=$ sea level at $\mathrm{t}$

$\mathrm{Ab}=$ tidal amplitude

$\omega=$ angular velocity $2 \pi \mathrm{f}$

$\mathrm{T}=$ time and $=$ phase delay.

Analysis of the tidal type (Formzahl ratio) at the study site used the equation [1][4]:

$\mathrm{F}=\left(\mathrm{K} \_1+\mathrm{O} \_1\right) /\left(\mathrm{M} \_2+\mathrm{S} \_2\right)$

based on the ratio formzahl can be grouped into the type of tide to form a value of $0<\mathrm{F}<0.25$ was double the daily tide of pure, $0: 25<\mathrm{F}<1.5$ mixture of double, 1.5 $<\mathrm{F}<3$ mixture of single and $\mathrm{F}>$ pure single. As for the observation of tides, a measuring pole (tide pole) with a scale of $\mathrm{cm}$ is used.

Generalization or bathymetry, the implementation procedure is by following the IHO standards for Hydrographic Survey. The sounding implementation uses an eagle 128 brand video-sounder, while the geographic position uses a Garmin C60 GPS with Universal Transverse Mercator (UTM) projections and a WGS 84 ellipsoid. - the fixing point of the sounding, usually the one used in the sounding lane is the direction perpendicular to the beach. For shoreline map results, the coordinates of the fix point and the measured depth (h-measurement), into the transducer (h-transducer), tides (h-tidal) are presented in table form. The measured depth is calculated by the tide correction number and the transducer is set to a depth of $30 \mathrm{~cm}$ during the measurement. The corrected depth formula is [1][4]:

$\mathrm{H}_{\text {plot }}=\mathrm{h}_{\text {ukur }}+\mathrm{h}_{\text {transducer }}-\mathrm{h}_{\text {pasut }}$

Where:

Hplot $=$ corrected depth, i.e., sea depth value from MLWS

$\mathrm{H}$ measuring = sea depth during sounding

$\mathrm{H}$ transducer $=$ transducer depth

$\mathrm{H}$ tide = water level from MLWS during sounding

Where this MLWS is the Mean Low Water Sea which is the lowest mean low tide [5].

\section{Results and Discussion}

\subsection{Tides Current in Tanjung Merah}

From the results of tidal current measurements with reference to data collection techniques, the results of data analysis from several depths can be seen in Figure 2 below. 


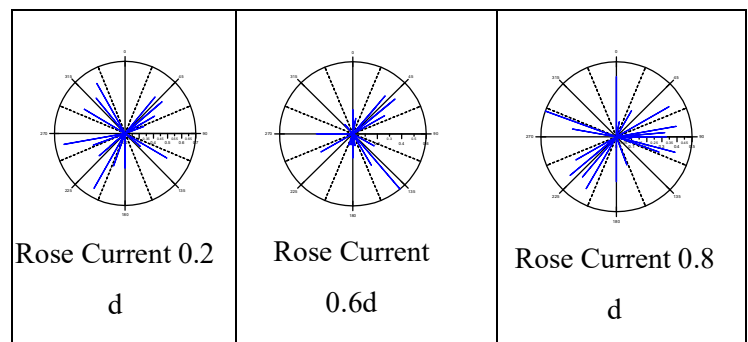

Fig.2. Rose Current Diagram in Tanjung Merah

The distribution pattern of tidal currents shows that the dynamics of the waters occur with the influence of depth at the measurement location. Current velocity data for the three depths varies between $0.2-0.3 \mathrm{~cm} / \mathrm{s}$ where at a depth of 2-meters the current velocity is $0.39 \mathrm{~cm} / \mathrm{s}$, indicating that the surface current is greater than the current at the bottom of the water. While the direction of the current velocity varies between $130^{\circ}-186^{\circ}$ in each depth which can be interpreted that the dominant current is heading south or out of the waters of Tanjung Merah.

\subsection{Tidal Condition in Tanjung Merah}

Tidal measurements were carried out for 15 days using the admiralty method. The purpose of this admiralty method using serial data used is short so quickly can provide water level location information at the time of the survey research. Tidal harmonic component is a key element in the assessment of sea level as shown in the table below

Table 1. Tidal Harmonics Components

\begin{tabular}{|c|c|c|c|c|c|c|c|c|c|c|}
\hline \multirow{2}{*}{ Location } & \multicolumn{10}{|c|}{ Tidal Component (cm) } \\
\cline { 2 - 12 } & S0 & M2 & S2 & N2 & K1 & O1 & M4 & MS4 & K2 & P1 \\
\hline \multirow{2}{*}{$\begin{array}{c}\text { Tanjung } \\
\text { Merah }\end{array}$} & 91,9 & 35,8 & 19,4 & 4,1 & 34,2 & 16,9 & 1,1 & 1,2 & 5,2 & 11,3 \\
\cline { 2 - 11 } & & 60,8 & 200,7 & 304,3 & 355,4 & 26,6 & 156,3 & 277,7 & 200,7 & 355,4 \\
\hline
\end{tabular}

As for the Formzahl (F) index, the results can be seen as follows:

Table 2. Index Formzhal

\begin{tabular}{|c|c|c|}
\hline Location & Index Formzhal & Tidal Type \\
\hline $\begin{array}{c}\text { Tanjung } \\
\text { Merah }\end{array}$ & 0,93 & Mixed Tide \\
\hline
\end{tabular}

The height difference for 15 days and the analysis of admiralty High Water Level (HWL), Mean Sea Level (MSL) and Low Water Level (LWL) is as follows as shown in the following table:

Table 3. Tidal height differences

\begin{tabular}{|c|l|c|}
\hline Symbol & \multicolumn{1}{|c|}{ Calculation } & Score \\
\hline HHWL & $\mathrm{Z}_{0}+\left(\mathrm{M}_{2}+\mathrm{S}_{2}+\mathrm{K}_{2}+\mathrm{K}_{1}+\mathrm{O}_{1}+\mathrm{P}_{1}\right.$ & 214,7 \\
MHWL & $\mathrm{Z}_{0}+\left(\mathrm{M}_{2}+\mathrm{K}_{1}+\mathrm{O}_{1}\right)$ & 178,7 \\
MSL & $\mathrm{Z}_{0}$ & 91,9 \\
MLWL & $\mathrm{Z}_{0}-\left(\mathrm{M}_{2}+\mathrm{K}_{1}+\mathrm{O}_{1}\right)$ & 5,0 \\
CDL & $\mathrm{Z}_{0}-\left(\mathrm{M}_{2}+\mathrm{S}_{2}+\mathrm{K}_{1}+\mathrm{O}_{1}\right)$ & $-14,4$ \\
LLWL & $\mathrm{Z}_{0}-\left(\mathrm{M}_{2}+\mathrm{S}_{2}+\mathrm{K}_{2}+\mathrm{K}_{1}+\mathrm{O}_{1}+\mathrm{P}_{1}\right)$ & $-30,9$ \\
LAT & $\mathrm{Z}_{0^{-}}($all constituents $)$ & $-37,2$ \\
\hline
\end{tabular}

Furthermore, the condition of the riding tide elevation that occurred in the study site in detail can be seen in the picture below.

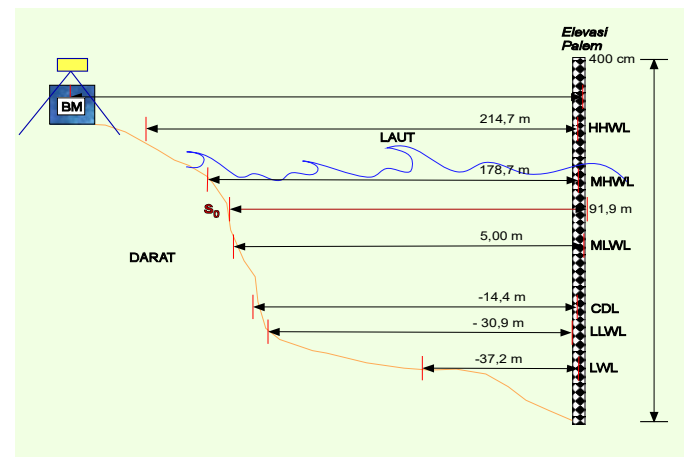

Fig.3 Tidal Elevation in Tanjung Merah

The nature of the tides of this location is the same as the sea and coastal waters of the Eastern part of Indonesia which have semidiurnal tidal properties. The ups and downs that occur at this location shown that in one day (24 hours) there are two (2) high and low tides but also interspersed with the age of the quarter (nearby) only one tide and low tide. So from the Formzhal index it is found that the tidal type is 0.93 which means that it is mixed with a single daily trend.

\subsection{Bathymetric Condition in Tanjung Merah}

The measurement data is then processed in the Surfer 15.0 application to produce contour lines with depth figures in meters. Bathymetric map can be seen in the following figure: 


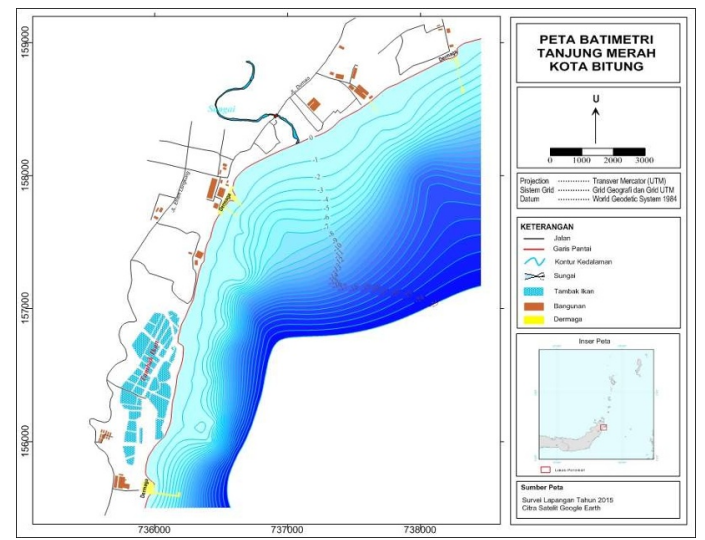

Fig.4. 2 - D Bathymetric Map

From the bathymetry map above, the depth contour is only at the limit of 30 with an interval of 1 , in meters. Then it can be seen in the figure showing very tight contour lines. In close contour lines, it shows the condition of the steep land surface. So that it can be defined the waters of Tanjung Merah as a steep beach.

The 3D model is the result of bathymetric data processing created using Surfer 15 software. The purpose of the 3D model is to analyze and explain the morphology of the beach. The results of the 3D model are shown in Figure 5 below:

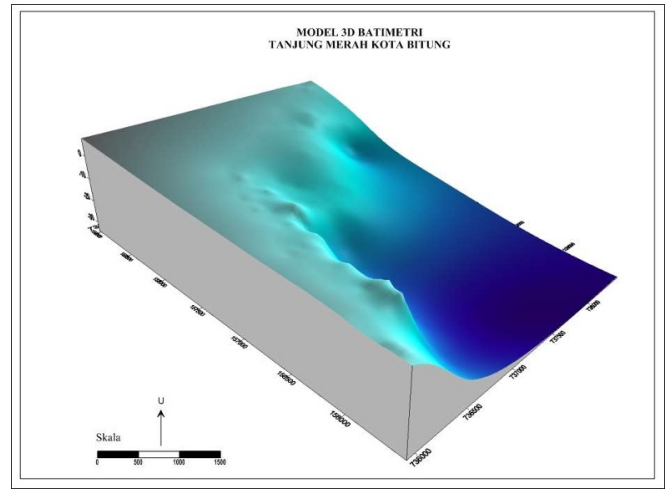

Fig.5. 3- D Bathymetric Map

From the results of the 3D model, it can be seen that the topography is rough and steep, then the image shows a different color classification, the light blue color is identified with a relative depth of lace, whereas the dark blue color is identified with a very high depth, from the color of the image above it can be concluded steep water conditions. Based on the calculation results, the highest depth at the research location is $-30.06 \mathrm{~m}$. These depth results have been corrected with tidal data. Then the tidal type in the study area is mixed with a single daily slope, so that the coastal abrasion process on the transport of coastal sediments is very high, so the beach in Tanjung Merah is very susceptible to erosion so that natural or artificial treatments are needed, such as by building a sea wall or the like at the same time doing conservation by planting suitable trees in the area. The depth of a waters can change due to the dynamics of the sea and the transport of coastal sediments. Then the bathymetry data is reprocessed using the Surfer 15 application, resulting in a bathymetry map. Based on the 2D bathymetry map in Figure 4, it shows a dense depth contour line at a depth of 2-30 m, only in the estuary part of the river which has a sparse contour line, the river estuary is often deposited so that this area is shallow. The 3D shape of Tanjung Merah beach morphology in Figure 5, shows an uneven seabed surface with a steep topography, so it can be identified that Tanjung Merah waters have deep beaches, these waters are suitable for shipping lanes. From this study, researchers provide depth data as a basis for assessing the physical condition of the waters in Tanjung Merah, presenting 2D and 3D bathymetry maps of coastal morphology, helping in analyzing the bottom face of the waters along the Tanjung Merah coast. This Bathymetry data is a database in the spatial assessment framework of the coastal spatial model in Bitung City.

\section{Conclusions}

Based on hydro-oceanographic data associated with the results of depth measurements (bathymetry) as well as making a 2D bathymetry map by showing depth contour lines and a 3D map showing topographical forms, then a cross-sectional profile of the beach is made to determine the morphology of the seabed in Tanjung Merah, Bitung City. it can be concluded that the waters at the study site have deep shores, this can be seen from the steep topography.

\section{References}

[1] M. Tendean, A. T. Moningkey, and J. C. Kumaat, "Pemanfaatan Data Hidro Oseanografi dan Batimetri Untuk Penataan Pantai Tatapaan, Minahasa Selatan,” Jurnal Episentrum, vol. 1, no. 1, p. 1, (2020).

[2] J. C. Kumaat, K. S. Andaria, and D. Maliangkay, "Analysis of Floating Net Cage Based on Geographic Information Syatem in Lembeh Island," IOP Conference Series: Materials Science and Engineering, vol. 1125, no. 1, p. 012024, May 2021.

[3] G. B. Bapeer and H. B. Bakir, "Applying Ground Penetrating Radar Current Meter Devices for Measuring Lesser Zab River Discharge in Taqtaq Area, Iraq," in International Iraqi Conference on Engineering Technology and its Applications, IICETA 2018, (2018).

[4] J. Kumaat, A. T. Moningkey, and M. Kumayas, "Studi tentang kondisi Hidro-Oseanografi dan Bathimetri Pantai Bajo - Popareng, Kabupaten Minahasa Selatan,” Zenodo, Jun. (2019).

[5] J. Kumaat, J. Haluan, B. Wiryawan, S. Wisudo, and D. Monintja, "Geometri Terumbu Pulau Kecil: Model Perencanaan Kawasan Konservasi Berbasis Perikanan Tangkap Di Kabupaten Kepulauan Sitaro (Reef Geometri Of Small Islands : A Model Conservation Planning Based On Fisheries Capture In Sitaro Archipelagic Regency)," Buletin PSP, (2012). 